\title{
31. OXYGEN AND CARBON ISOTOPIC COMPOSITION OF BENTHIC FORAMINIFERS AT DEEP SEA DRILLING PROJECT SITES 548 AND 549 (HOLE 549A): PLEISTOCENE CLIMATIC CHANGES AND CIRCULATION IN THE NORTHEASTERN ATLANTIC ${ }^{1}$
}

\author{
C. Vergnaud Grazzini and J. F. Saliège, Département de Géologie Dynamique²
}

\begin{abstract}
Oxygen and carbon isotopic compositions of benthic foraminifers Planulina wuellerstorfi, Uvigerina peregrina, and Cibicides kullenbergi from DSDP Holes 548 and 549A in the northeastern Atlantic reveal two modes of isotopic variation in the Pleistocene, linked with glacial conditions and oceanographic evolution in the region of deep-water sources. The lower Pleistocene is characterized by more highly oxygenated deep waters, less pronounced glacial extremes, and glacial-interglacial $\delta^{18} \mathrm{O}$ variations of lower amplitude than for the last 425,000 yrs., as documented here. A $1 \% 0$ difference between $\delta^{18} \mathrm{O}$ glacial maximal values of the lower and upper Pleistocene cannot have resulted from a change in ice volume alone. Less-oxygenated and colder North Atlantic Deep Water of the upper Pleistocene may indicate a major northward penetration and increased inflow rate of Antarctic Bottom Water.
\end{abstract}

\section{INTRODUCTION}

Oxygen and carbon isotopic analyses have been performed on benthic foraminifers from the Quaternary sediments recovered at Sites 548 and 549 (Hole 549A) in the northern part of the Bay of Biscay (Fig. 1).

\begin{tabular}{lccccc}
\hline Hole & $\begin{array}{c}\text { Latitude } \\
(\mathrm{N})\end{array}$ & $\begin{array}{c}\text { Longitude } \\
(\mathrm{W})\end{array}$ & $\begin{array}{c}\text { Water } \\
\text { depth } \\
(\mathrm{m})\end{array}$ & $\begin{array}{c}\text { Drilling in } \\
\text { Quaternary } \\
(\mathrm{m})\end{array}$ & $\begin{array}{c}\text { Number of } \\
\text { samples }\end{array}$ \\
\hline 548 & $48^{\circ} 54.95^{\prime}$ & $12^{\circ} 09.84^{\prime}$ & 1256.0 & 110 & $\begin{array}{c}24 \text { (Cores } \\
9 \text { to } 15) \\
50(\text { Cores } \\
1 \text { to 3) }\end{array}$ \\
\hline $549 \mathrm{~A}$ & $49^{\circ} 05.23^{\prime}$ & $13^{\circ} 05.89^{\prime}$ & 2535.5 & 27 & $\begin{array}{c}27 \\
\end{array}$ \\
\hline
\end{tabular}

These sites are located on a transect across the Goban Spur, a submerged ridge extending from the continental slope to the abyssal plain.

Water depth indicated that Site 548 is presently situated in the Arctic Intermediate Waters, where physicochemical parameters of water might be influenced by Mediterranean outflow water and North Atlantic Deep Water (NADW) (Tchernia, 1978). Site 549 is situated in the core of the NADW.

According to previous works, this region of the eastern North Atlantic has undergone important hydrological changes in response to repetitive climatic fluctuations during Pleistocene time (for extensive literature, see $\mathrm{Pu}$ jol, 1980). As an example, during the last glacial maximum, these sites may have been located north of the polar front and the subarctic convergence (both recognized at $42^{\circ} \mathrm{N}$; McIntyre at al., 1976).

In addition, faunal analyses (Schnitker, 1974, 1976, 1979, 1980, 1982; Peypouquet, 1977; Belanger, 1982), stable-isotope analyses (Duplessy et al., 1980), combined faunal and stable-isotope analyses (Streeter and Shack-

\footnotetext{
${ }^{1}$ Graciansky, P. C. de, Poag, C. W., et al., Init. Repts. DSDP, 80: Washington (U.S. Govt, Printing Office). France.

2 Address: Département de Géologie Dynamique, 4 place Jussieu, 75230 Paris Cedex 05,
}

leton, 1979; Curry and Lohmann, 1982), and geochemical analyses (Boyle and Keigwin, 1982; Broecker, 1982) have shown that, during glacial stages, deep Atlantic circulation underwent severe changes either in the characteristics and locations of deep-water sources or in the flow rate of NADW. Whether NADW continued to form (Duplessy et al., 1980; Vergnaud Grazzini et al., in press) during glacial maxima or was reduced or even eliminated (Corliss, 1982; Curry and Lohmann, 1982) is still a matter of controversy. It is clear, however, that stable-isotopic data alone cannot be a satisfactory indicator of thermohaline flow.

The results presented here concern only stable-isotopic changes in benthic foraminifers. Although preliminary, this approach makes available some new data on a whole Pleistocene record in the northeastern Atlantic; it emphasizes the occurrence of important hydrological changes at periods not always related to maximal icecap extension.

\section{METHODS}

Benthic foraminifers for isotopic analyses were separated and determined by Caralp (this vol.). Samples were ultrasonically cleaned in distilled water and dried and roasted at $350^{\circ} \mathrm{C}$ in vacuum for half an hour. Analytical procedures for the isotopic analyses of carbonate followed those of Shackleton and Opdyke (1973). Samples were reacted with $100 \%$ orthophosphoric acid at $50^{\circ} \mathrm{C}$ in an oven. Evolved gas samples, after a series of distillation steps to get pure $\mathrm{CO}_{2}$, were analyzed in an on-line VG Micromass $602 \mathrm{C}$ mass spectrometer. All isotopic data are refered to PDB references in the standard $\delta$ notation through the use of intercalibration standards. The analytical precision of the carbonate standard run during the period of the investigation is $\pm 0.09(1 \sigma)$ for $\delta^{18} \mathrm{O}$ and $\pm 0.09(1 \sigma)$ for $\delta^{13} \mathrm{C}$. The standard deviation of repeated analyses of the same foraminiferal species in Quaternary sediments is $\sigma= \pm 0.14$ for $\delta^{18} \mathrm{O}$ and \pm 0.08 for $\delta^{13} \mathrm{C}$; this last evaluation takes into account more sources of uncertainty such as laboratory errors, isotopic variability among specimens, and analytical precision.

Another source of uncertainty is introduced by estimating the factor by which analyses for different species may be corrected for departure from isotopic equilibrium. This is discussed in the next section.

\section{ISOTOPIC DATA}

Oxygen and carbon isotopic data are given in Tables 1 and 2 and are plotted in Figures 2 and 3 as a function 


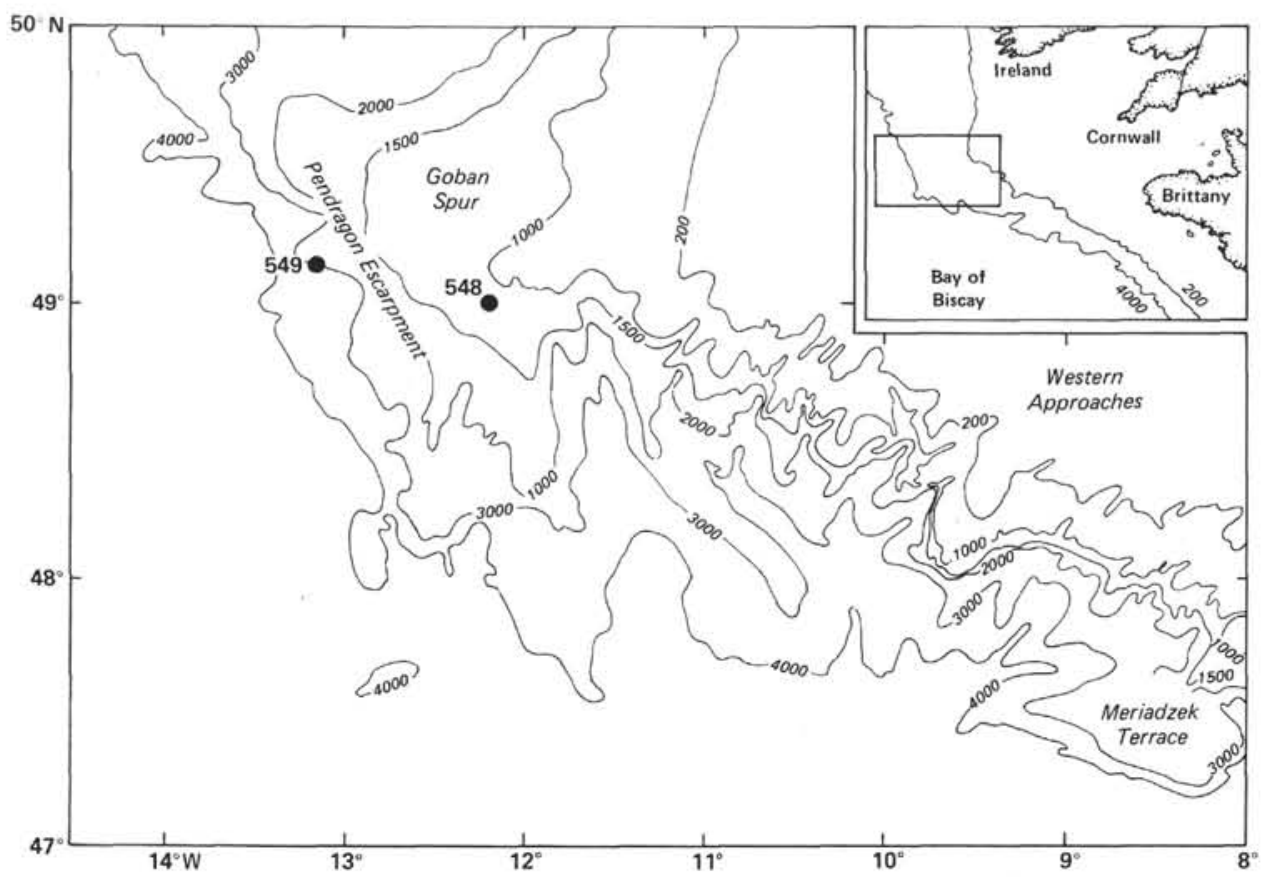

Figure 1. Location of Sites 548 and 549, northwest of the Bay of Biscay. Inset of upper right map is area of main map. (Water depths in meters.)

of depth in the hole. For Hole 549A analyses were made in the three upper cores, 1 to 3 , down to $27 \mathrm{~m}$ sub-bottom; For Hole 548, analyses were made from Core 9 (72 $\mathrm{m}$ sub-bottom) down to Core $15(106 \mathrm{~m})$. At some levels, benthic foraminifers were scarce and could not be analyzed, so some intervals appear without isotopic data.

The most frequent species analyzed were as follows: (Hole 549A) Planulina wuellerstorfi and Uvigerina peregrina; (Hole 548) $P$. wuellerstorfi, U. peregrina, Cibicides kullenbergi, Hoeglundina spp., and Bulimina spp. C. kullenbergi is the most frequent species at the shallower Site 548; $P$. wuellerstorfi and $U$. peregrina are frequent at Site 549 (Hole 549A). This difference in the species assemblages of the two sites clearly reflects the environmental characteristics of two different water masses.

The magnitude of isotopic disequilibrium in some or all of these species has been studied by various authors (Woodruff et al., 1980; Shackleton, 1974; Belanger et al., 1981; Graham et al., 1981). In this chapter, we have used the calibrations proposed by Graham et al. (1981); these last authors did not evaluate the disequilibrium in Bulimina, but from our own observations it appears that this species secretes calcite in oxygen-isotopic equilibrium, with values close to those of Uvigerina.

Thus, the following $\Delta$ deviations were used:

\begin{tabular}{lcc}
\hline \multicolumn{1}{c}{ Species } & $\begin{array}{c}\Delta^{18} \mathrm{O} \text { mean deviation } \\
\text { from } \text { Uvigerina spp. }\end{array}$ & $\begin{array}{l}\Delta^{13} \mathrm{C} \text { mean deviation } \\
\text { from } P \text {. wuellerstorfi }\end{array}$ \\
\hline P. wuellerstorfi & -0.69 & 0.00 \\
Uvigerina spp. & 0.00 & -0.77 \\
C. kullenbergi & -0.73 & -0.10 \\
Hoeglundina spp. & +0.34 & +1.50 \\
Bulimina spp. & 0.00 & $?$ \\
\hline
\end{tabular}

where the mean isotopic deviations are (1) (from Uvigerina spp.) $\Delta^{18} \mathrm{O}=\delta_{\text {species }}-\delta$ Uvigerina and (2) (from $P$. wuellerstorfi) $\Delta^{13} \mathrm{C}=\delta_{\text {species }}-\delta P$. wuellerstorfi .

\section{Oxygen Isotopic Stratigraphy}

At the deeper Site 549 (Hole 549A), oxygen data for $P$. wuellerstorfi and $U$. peregrina, plotted against depth in the hole (Table 1 and Fig. 2), enable us to recognize the glacial-interglacial pattern of oxygen-isotopic variations and to correlate it with oxygen-isotopic stages of Emilani $(1955,1966)$ and Shackleton and Opdyke (1973), down to isotopic stage 13 . This chronological interpretation is confirmed by the LAD of Pseudoemiliania lacunosa at about $20 \mathrm{~m}$ sub-bottom (Section 549A-3-2; Caralp et al., this vol.). In the lower part of Core 549A-3 (Sections 4-6), samples are too widely spaced with respect to the low sediment accumulation rate in that part of the sequence, and do not allow identification of any older stages. Additional stratigraphic information is provided by analysis of weight percent carbonate and the study of planktonic foraminiferal variations by Pujol and Duprat (this vol.), whose proposed bioclimatic zonation for this site is in good agreement with our oxygen-isotopic stratigraphy for the upper 12 stages.

The glacial-interglacial difference in $\delta^{18} \mathrm{O}$ averages approximately $2.2 \%$. This average is calculated using $\delta^{18} \mathrm{O}$ minima of all interglacial stages except the present one. For all of them, the minimal $\delta^{18} \mathrm{O}$ values are lower than present-day values by about $0.5 \%$. As mentioned, the present bottom water at DSDP Site 549 is NADW, with $t$ $=3.5^{\circ} \mathrm{C}$ and $\delta^{18} \mathrm{O}=+0.12$ versus SMOW (Craig and Gordon, 1965). The measured $\delta^{18} \mathrm{O}$ value for Uvigerina is +3.42 at the top of the first core; using the temperature scale established by Shackleton (1974) for low tem- 
Table 1. Oxygen and carbon analyses (\%) for Site 549 (Hole 549A).

\begin{tabular}{|c|c|c|c|c|c|c|}
\hline \multirow{3}{*}{$\begin{array}{l}\text { Core-Section } \\
\text { (level in } \mathrm{cm} \text { ) }\end{array}$} & \multirow{3}{*}{$\begin{array}{l}\text { Sub-bottom } \\
\text { depth (m) }\end{array}$} & \multirow[b]{3}{*}{ Species } & \multirow{3}{*}{$\delta^{18} \mathrm{O}$} & \multirow{3}{*}{$\delta^{13} \mathrm{C}$} & $\delta^{18} \mathrm{O}^{\mathrm{a}}$ & $\delta^{13} \mathrm{C}^{\mathrm{a}}$ \\
\hline & & & & & \multicolumn{2}{|c|}{ corrected against } \\
\hline & & & & & Uvigerina & Planulina \\
\hline $1-1,1$ & & Uvigerina peregrina & +3.42 & -0.16 & +3.42 & +0.61 \\
\hline $1-1,8$ & & Planulina wuellerstorfi & +2.37 & +0.30 & +3.06 & +0.30 \\
\hline $1-1,39$ & & P. wuellerstorfi & +3.02 & +0.19 & +3.71 & +0.19 \\
\hline $1-3,125$ & & P. wuellerstorfi & +2.88 & +0.63 & +3.57 & +0.63 \\
\hline $1-4,10$ & & P. wuellerstorfi & +2.82 & +0.66 & +3.51 & +0.66 \\
\hline $1-4,20$ & & P. wuellerstorfi & +3.09 & +0.41 & +3.78 & +0.41 \\
\hline $1-4,40$ & & P. wuellerstorfi & +2.02 & +0.38 & +2.71 & +0.38 \\
\hline \multirow[t]{2}{*}{$1-4,72$} & & P. wuellerstorfi & +4.25 & +0.10 & +4.94 & +0.10 \\
\hline & & U. peregrina & +5.27 & -0.82 & +5.27 & -0.05 \\
\hline $1-4,88$ & & $U$. peregrina & +4.96 & -1.16 & +4.96 & -0.39 \\
\hline $1-4,100$ & & $U$. peregrina & +5.21 & -0.99 & +5.21 & -0.22 \\
\hline $1-5,144$ & 7.47 & $U$. peregrina & +4.98 & -0.79 & +4.99 & -0.02 \\
\hline $2-1,3$ & & P. wuellerstorfi & +2.99 & +0.70 & +3.68 & +0.70 \\
\hline \multirow[t]{2}{*}{$2-1,10$} & & P. wuellerstorfi & +3.38 & +0.24 & +4.07 & +0.24 \\
\hline & & $U$. peregrina & +4.64 & -0.89 & +4.64 & -0.12 \\
\hline $2-1,55$ & & $U$. peregrina & +3.46 & -1.65 & +3.46 & -0.88 \\
\hline $2-1,102$ & & P. wuellerstorfi & +3.22 & +0.73 & +3.91 & +0.73 \\
\hline $2-1,135$ & & P. wuellerstorfi & +3.95 & +0.25 & +4.64 & +0.25 \\
\hline \multirow[t]{2}{*}{$2-2,10$} & & $P$ wuellerstorfi & +3.35 & +0.36 & +4.04 & +0.36 \\
\hline & & $U$. peregrina & +4.49 & -0.40 & +4.49 & +0.37 \\
\hline \multirow[t]{2}{*}{$2-2,20$} & & P. wuellerstorfi & +2.34 & +0.40 & +3.03 & +0.40 \\
\hline & & $U$. peregrina & +4.33 & -0.79 & +4.33 & +0.56 \\
\hline $2-2,56$ & & P. wuellerstorfi & +3.50 & +0.20 & +4.19 & +0.20 \\
\hline $2-2,95$ & & P. wuellerstorfi & +2.69 & +0.46 & +3.38 & +0.46 \\
\hline $2-2,100$ & & P. wuellerstorfi & +3.22 & +0.73 & +3.91 & +0.73 \\
\hline $2-2,130$ & & P. wuellerstorfi & +3.95 & +0.25 & +4.64 & +0.25 \\
\hline $2-3,20$ & & $U$. peregrina & +4.00 & -0.81 & +4.00 & -0.04 \\
\hline $2-3,58$ & & $P$ wuellerstorfi & +3.84 & +0.95 & +4.53 & +0.95 \\
\hline $2-3,95$ & & P. wuellerstorfi & +3.02 & +0.59 & +3.71 & +0.59 \\
\hline \multirow[t]{2}{*}{$2-3,107$} & & $P$ wuellerstorfi & +1.88 & +0.10 & +2.57 & +0.10 \\
\hline & & $U$. peregrina & +2.14 & -1.20 & +2.14 & -0.43 \\
\hline $2-4,74$ & & $U$. peregrina & +4.89 & -0.12 & +4.89 & +0.99 \\
\hline $2-4,74$ & & Hoeglundina & +5.59 & +1.41 & +5.25 & -0.09 \\
\hline $2-5,10$ & & $U$. peregrina & +3.79 & -0.97 & +3.79 & -0.20 \\
\hline $2-5,20$ & & $U$. peregrina & +2.66 & -0.90 & +2.66 & -0.13 \\
\hline $2-5,50$ & & $U$. peregrina & +4.49 & & +4.49 & \\
\hline $2-5,80$ & & $U$. peregrina & +3.22 & -0.92 & +3.22 & -0.15 \\
\hline $2-6,20$ & & $U$. peregrina & +4.03 & -1.58 & +4.03 & -0.81 \\
\hline $2-6,64$ & & $U$. peregrina & +4.53 & -1.43 & +4.53 & -0.66 \\
\hline $2-6,103$ & 16 & $U$. peregrina & +4.00 & -0.28 & +4.00 & +0.49 \\
\hline $3-1,2$ & & $U$. peregrina & +3.46 & -0.45 & +3.46 & +0.32 \\
\hline $3-1,7$ & & U. peregrina & +4.64 & -2.00 & +4.64 & -1.23 \\
\hline $3-1,40$ & & $U$, peregrina & +4.91 & -2.08 & +4.91 & -1.31 \\
\hline $3-1,89$ & & $U$. peregrina & +4.61 & -1.83 & +4.61 & -1.06 \\
\hline $3-2,40$ & & $U$. peregrina & +4.94 & -0.83 & +4.94 & -0.06 \\
\hline $3-2,86$ & & $U$. peregrina & +4.16 & -0.69 & +4.16 & +0.08 \\
\hline \multirow[t]{2}{*}{$3-2,115$} & & $U$ peregrina & +4.17 & -0.02 & +4.17 & +0.75 \\
\hline & & P. wuellerstorfi & +2.55 & +0.39 & +3.24 & +0.39 \\
\hline $3-2,138$ & & P. wuellerstorfi & +3.65 & +0.47 & +4.34 & +0.47 \\
\hline $3-2,147$ & & P. wuellerstorfi & +3.04 & +0.77 & +3.73 & +0.77 \\
\hline $3-3,29$ & & $U$. peregrina & +2.80 & -0.22 & +2.80 & +0.55 \\
\hline $3-3,41$ & & $U$. peregrina & +3.78 & -0.08 & +3.78 & +0.71 \\
\hline $3-3,132$ & & P. wuellerstorfi & +3.24 & -0.06 & +3.93 & -0.06 \\
\hline $3-4,47$ & & P. wuellerstorfi & +3.29 & -0.31 & +3.98 & -0.31 \\
\hline $3-4,112$ & & U. peregrina & +3.31 & -0.80 & +3.31 & -0.03 \\
\hline $3-5,80$ & & P. wuellerstorfi & +3.70 & +0.71 & +4.39 & +0.71 \\
\hline $3-6,46$ & & P. wuellerstorfi & +2.70 & -0.43 & +3.39 & -0.43 \\
\hline $3-6,80$ & & P. wuellerstorfi & +3.40 & +0.12 & +4.09 & +0.12 \\
\hline $3, \mathrm{CC}(15-22)$ & 27 & P. wuellerstorfi & +3.18 & +0.13 & +3.87 & +0.13 \\
\hline
\end{tabular}

peratures $\left(t^{\circ} \mathrm{C}=16.9-4\left[\delta_{c}-\delta_{w}\right]\right),{ }^{3}$ we may calculate an isotopic temperature around $+3 \pm 0.4^{\circ} \mathrm{C}$, in agreement with modern conditions. However, the present-day $\delta^{18} \mathrm{O}$ equilibrium value of $+3.42 \%$ is higher than older interglacial $\delta^{18} \mathrm{O}$ values, which average $+2.65 \%$.

\footnotetext{
${ }^{3}$ Where $\delta_{c}=\delta^{18} \mathrm{O}$ of the carbonate analyzed and $\delta_{w}=\delta^{18} \mathrm{O}$ of the $\mathrm{CO}_{2}$ equilibrated with the water, where the carbonate has precipitated, and measured against the same reference.
}

When compared with the present-day value of $+3.42 \%$, $\delta^{18} \mathrm{O}$ glacial values are higher by 1.6 to $1.9 \%$.

At the shallower Site 548, oxygen isotopic data correspond to the Matuyama magnetic period. Widely spaced samples lead to an isotopic curve with only three apparent glacial-interglacial cycles. The faunal curves are also poorly documented, although Pujol and Duprat (this vol.) have been able to recognize 12 bioclimatic subdivisions in the same period. During this time, interglacial 
Table 2. Oxygen and carbon isotopic analyses $(\%$ ) for Site 548 (Hole 548).

\begin{tabular}{|c|c|c|c|c|c|c|}
\hline \multirow[b]{2}{*}{$\begin{array}{l}\text { Core-Section } \\
\text { (level in } \mathrm{cm} \text { ) }\end{array}$} & \multirow[b]{2}{*}{$\begin{array}{l}\text { Sub-bottom } \\
\text { depth }(\mathrm{m})\end{array}$} & \multirow[b]{2}{*}{ Species } & \multirow[b]{2}{*}{$\delta^{18} \mathrm{O}$} & \multirow[b]{2}{*}{$\delta^{13} \mathrm{C}$} & \multicolumn{2}{|c|}{$\begin{array}{c}\delta^{18} \mathrm{O}^{\mathrm{a}} \quad \delta^{13} \mathrm{C}^{\mathrm{a}} \\
\text { corrected against }\end{array}$} \\
\hline & & & & & $\begin{array}{l}\text { corrected } \\
\text { Uvigerina }\end{array}$ & $\begin{array}{l}\text { against } \\
\text { Planulina }\end{array}$ \\
\hline $9-2,20$ & 71.7 & Planulina wuellerstorfi & +2.96 & +1.03 & +3.65 & +1.03 \\
\hline $9-2,108$ & & P. wuellerstorfi & & +0.24 & & +0.24 \\
\hline $10-4,43$ & & Hoeglundina & +4.36 & & +4.02 & \\
\hline $10-4,114$ & & P. wuellerstorfi & +2.06 & +0.47 & +2.75 & +0.47 \\
\hline $10-5,43$ & & P. wuellerstorfi & +1.29 & +0.02 & +1.98 & +0.02 \\
\hline $10-6,54$ & & Cibicides kullenbergi & +2.91 & +0.65 & +3.64 & +0.75 \\
\hline $11-1,140$ & 81.4 & P. wuellerstorfi & +3.36 & +0.52 & +4.05 & +0.52 \\
\hline $11-3,139$ & & C. kullenbergi & +3.06 & +0.63 & +3.79 & +0.73 \\
\hline & & Bulimina spp. & +3.58 & -0.29 & +3.58 & \\
\hline $11-5,17$ & & C. kullenbergi & +2.99 & +0.35 & +3.72 & +0.45 \\
\hline $11-5,92$ & & C. kullenbergi & +2.70 & +0.16 & +3.43 & +0.26 \\
\hline $11-5,143$ & & C. kullenbergi & +1.90 & +0.33 & +2.63 & +0.43 \\
\hline $11-6,8$ & & C. kullenbergi & +2.21 & +0.04 & +2.94 & +0.14 \\
\hline $13-1,130$ & 93.3 & C. kullenbergi & +1.44 & -0.08 & +2.17 & +0.02 \\
\hline $13-3,22$ & & C. kullenbergi & +2.28 & +0.41 & +3.01 & +0.51 \\
\hline $13-3,130$ & & C. kullenbergi & +2.67 & -0.04 & +3.40 & +0.06 \\
\hline $13-4,35$ & & C. kullenbergi & +2.05 & +0.31 & +3.78 & +0.41 \\
\hline $13-5,35$ & & P. wuellerstorfi & +1.76 & +0.43 & +2.45 & +0.43 \\
\hline $13-5,130$ & & Uvigerina peregrina & $+1.20(?)^{\mathrm{b}}$ & & $+120(?)$ & \\
\hline $13-6,27$ & & C. kullenbergi & +3.57 & +0.34 & +4.30 & +0.44 \\
\hline $14-1,40$ & 99.4 & C. kullenbergi & +2.38 & +0.22 & +3.11 & +0.32 \\
\hline $15-1,112$ & 101.1 & P. wuellerstorfi & +1.73 & $-0.30(?)$ & +2.42 & $-0.30(?)$ \\
\hline $15-5,30$ & & C. kullenbergi & +3.41 & +0.55 & +4.14 & +0.65 \\
\hline $15-5,63$ & 106.6 & C. kullenbergi & +2.36 & +0.08 & +3.09 & +0.18 \\
\hline
\end{tabular}

$\delta^{18} \mathrm{O}$ minimal values averaged $+2.33 \%$, and glacial $\delta^{18} \mathrm{O}$ maximal values averaged $+4.0 \%$. This results in a lower amplitude of the $\delta^{18} \mathrm{O}$ variations $(1.67 \%$ ) than in the upper Pleistocene $(2.2 \% 0)$.

It has been shown in other Pleistocene cores that glacial extremes in the early Pleistocene were significantly less intense than those of the middle and late Pleistocene. Intensification of the glacial effect was worldwide, appearing in both the Pacific and the North and South Atlantic; at some locations, this intensification has been identified around isotopic stage 22 (Shackleton and Opdyke, 1976, Shackleton and Cita, 1979; Vergnaud Grazzini et al., in press). Available isotopic data do not permit us to propose a precise timing of this intensification at Sites 548 and 549; but they suggest that sediments deposited earlier than those of Core 548-10 date from the early Pleistocene, for which glacial-interglacial cycles have been recorded which have a lower amplitude than those of the more recent $450,000 \mathrm{yrs}$.

\section{Carbon Isotopic Data}

The carbon isotopic data for the two sites are plotted against depth in the hole in Figures 2 and 3.

At Site 549 , the mean $\delta^{13} \mathrm{C}$ value is about $+0.16 \%$; at Site 548 , the mean value is about $+0.34 \%$. The total range of carbon isotopic composition is $2.2 \%$ at Site 549 (about -1.31 to +0.95 ); it is only $+1.0 \%$ at Site 548 (about +0.02 to +1.03 ).

\section{Present Hydrological Features and Faunal Assemblages}

The North Atlantic Deep Water is a young water mass, having been formed relatively recently from water flowing out of the Norwegian Sea and the Labrador Sea. Toward $45^{\circ} \mathrm{N}$, NADW characteristics are strongly dependent on those of the different water masses that compose it. On a vertical depth profile, in fact, one could recognize two well-oxygenated water masses: the Arctic Bottom Water below $\left(t \cong 2.5^{\circ} \mathrm{C}, S \%_{0} \cong 35.02\right)$, formed from the Norwegian outflow over the sills of the Denmark Strait and the Ireland-Faeroe Ridge, and the Labrador Deep Water above $\left(3.0<t^{\circ} \mathrm{C}<3.5 ; 34.88<\right.$ $\left.S \%_{0}<34.94\right)$. These two water masses are formed by the same process of cooling and sinking of surface water either in the Norwegian Sea or in the Labrador Sea. Because they have been isolated from the surface for such a short time, these waters have a high oxygen content: $6.0<\mathrm{O}_{2}<6.6 \mathrm{ml} \cdot 1^{-1}$ for the Labrador Deep Water. This core of well-oxygenated waters is sandwiched, at this latitude, by two poorly oxygenated water masses: a strongly modified Antarctic Bottom Water $\left(t \cong 2.5^{\circ} \mathrm{C}\right)$ below and Mediterranean waters above $\left(\mathrm{O}_{2}<4.5 \mathrm{ml}\right.$. $\left.1^{-1}\right)$. Intermediate Arctic Waters, which form during winter east of Newfoundland at $45^{\circ} \mathrm{N}\left(3.0<t^{\circ} \mathrm{C}<5.0\right.$; $34.7<S \%<34.9$ ), may be found at the level of, or slightly above, Mediterranean waters. Regional studies of deep-water North Atlantic foraminifers have shown that their distribution is strongly controlled by the occurrence of distinct water masses. For instance, faunal association with Planulina wuellerstorfi occurs in samples from areas of NADW influence; faunal associations dominated by Uvigerina peregrina occur in conjunction with relatively warm and saline water that is in large part of Mediterranean origin. In fact, Streeter and Shackleton (1979) remarked that between 2000 and 4000 $\mathrm{m}$ in the whole Atlantic, the distribution of $U$. peregrina 


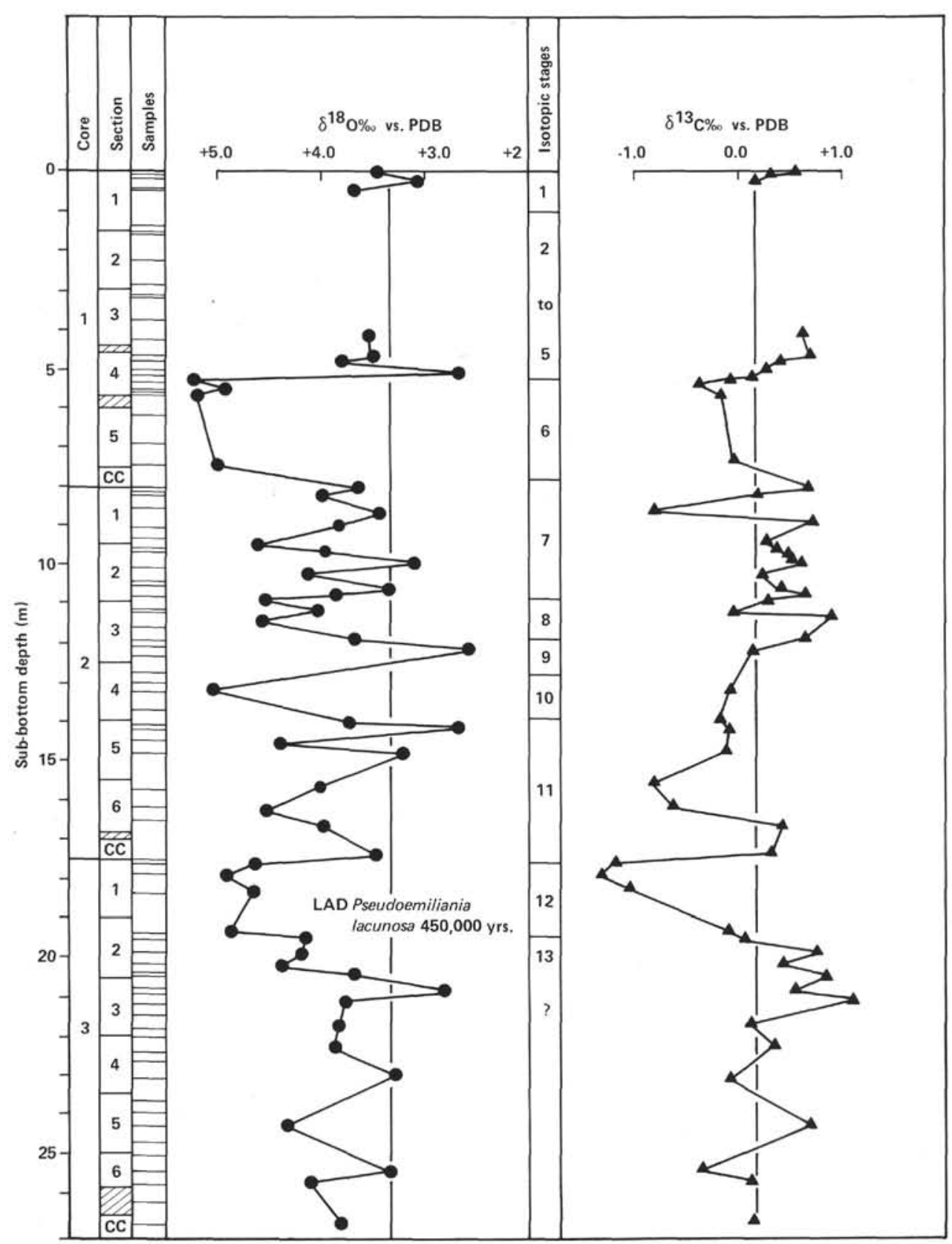

Figure 2. Oxygen and carbon isotopic compositions of benthic foraminifers plotted against depth in DSDP Hole 549A. Present-day $\delta^{18} \mathrm{O}$ value and the mean carbon isotopic value of the data set $\left(\delta^{13} \mathrm{C}=\right.$ $0.16 \%$ pDB $)$ are shown by vertical lines.

is generally congruent with the distribution of dissolved oxygen, even though oxygen may not really be the ecologically limiting variable; it has been noted, however, that $U$. peregrina becomes an important component of the fauna when the oxygen content falls below about 5 $\mathrm{ml} \cdot \mathrm{l}^{-1}$. At present, this species is absent from the welloxygenated core of NADW. In the North and equatorial Atlantic, it occurs in an intermediate oxygen-minimum (IOM) to which Mediterranean outflow largely contributes. In the present-day Mediterranean, too, the genus Uvigerina is abundant in waters of low oxygen content $\left(\leq 4.5 \mathrm{ml} \cdot 1^{-1}\right)$ down to $1500 \mathrm{~m}$ depth.

\section{DISCUSSION: DEEP-SEA ENVIRONMENT AND GLACIAL CYCLES}

\section{Two Different Glacial Modes}

Comparison of the oxygen isotopic records for Sites 548 and 549 suggests two different glacial modes. The older one, corresponding to the so-called preglacial Pleistocene, is characterized by lower-amplitude glacial-interglacial $\delta^{18} \mathrm{O}$ variations (less than $1.7 \%$ ); this suggests either a smaller ice volume than today or the absence of any cooling effect in the water masses. Maximal $\delta^{18} \mathrm{O}$ values, corresponding to glacial peaks, are generally less 


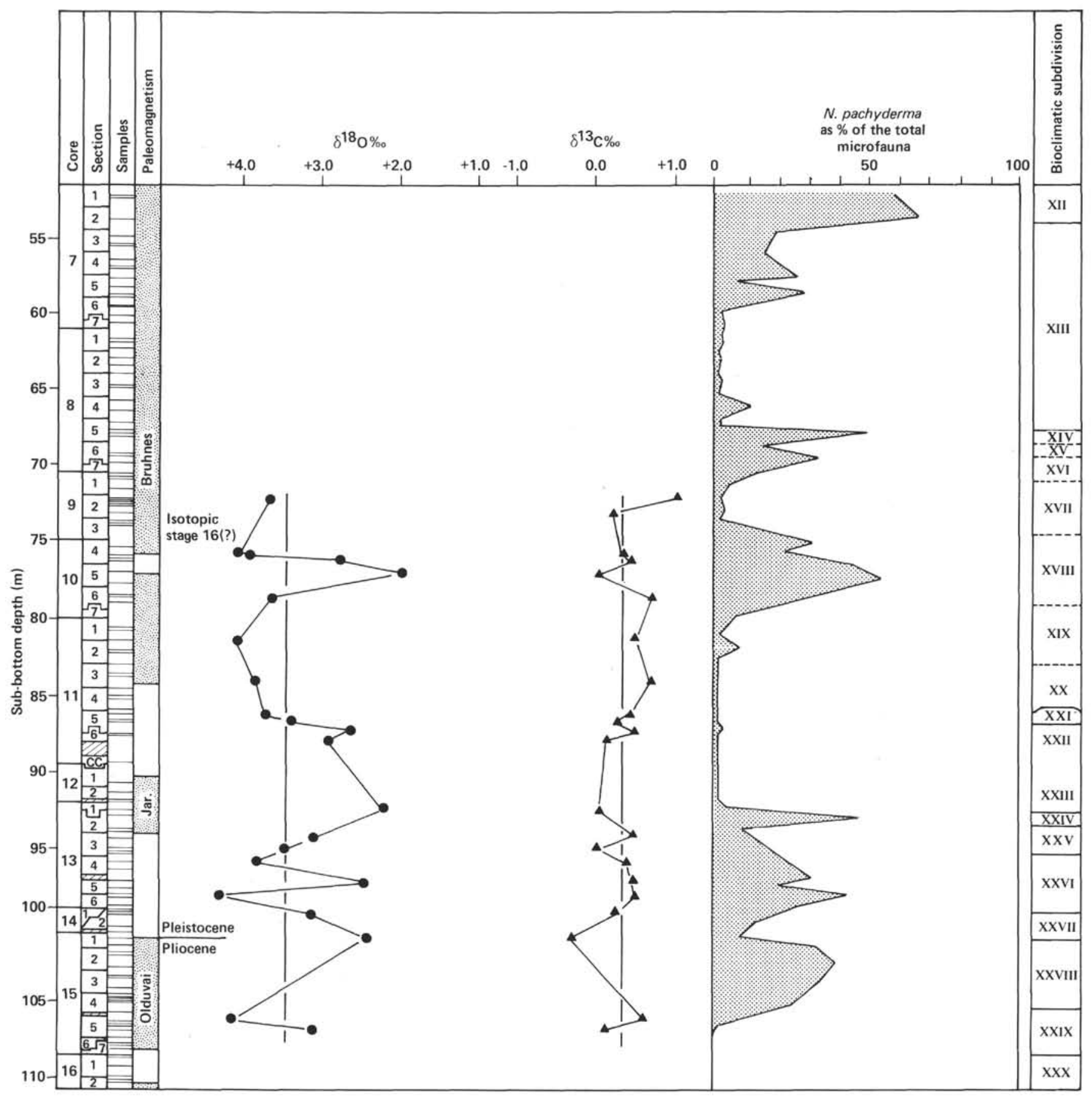

Figure 3. Oxygen and carbon isotopic compositions of benthic foraminifers plotted against depth in DSDP Hole 548. Present-day value of $\delta^{18} \mathrm{O}$ $(+3.42 \% 0)$ and the mean carbon isotopic value of the data set $\left(\delta^{13} \mathrm{C}=+0.34 \%\right.$ pDB $)$ are shown by vertical lines. On the right are shown percentages of the total microfauna represented by $N$. pachyderma, plotted against bioclimatic subdivisions according to Pujol and Duprat (this vol.).

than $+4.25 \%$, whereas they reach $+5.25 \%$ in the upper Pleistocene of Hole 549A. Several workers have observed that a global climatic change occurred in the middle Pleistocene, which is recorded either by faunal assemblages or by their isotopic compositions, as in these instances:

1. The abundance of Sphaeroidinella dehiscens decreases sharply near the top of the Jaramillo magnetic event in cores from the Atlantic Ocean (Berggren et al., 1967; Phillips et al., 1968) and across the Bruhnes/Ma- tuyama boundary in Atlantic and Pacific cores (Glass et al., 1967).

2. Faunal changes in equatorial Atlantic cores within and above the Jaramillo event indicate a significant cooling (Berggren, 1968).

3. Sea-surface temperatures estimated through foraminifer-based transfer functions for the tropical North Atlantic Core V 16-205 (Briskin and Berggren, 1975) indicate two types of cold regime, with a transition occurring near the end of the Jaramillo event. 
4. In the same tropical Atlantic core, V 16-205, Van Donk (1976) found that the isotopic fluctuations below the Bruhnes/Matuyama boundary were of smaller amplitude than those within the Bruhnes normal epoch.

5. Shackleton and Opdyke (1976) observed the same isotopic pattern in Pacific Core V 28-239 and suggested that glacial isotopic stage 22, above the Jaramillo event, may represent the first major Northern Hemisphere continental glaciation of the middle Pleistocene.

6. More recently, Vergnaud Grazzini et al. (1983), in a Pleistocene isotopic record at Hole 517F, found that glacial extremes earlier than isotopic stage 22 (about 900,000 yrs. ago) were significantly less intense than those of the middle and late Pleistocene, the difference in maximum $\delta^{18} \mathrm{O}$ values being around $1.0 \%$. These authors have related this finding to a substantial increase in the ice-cap volume; but, since a $\delta^{18} \mathrm{O}$ increase of $1.0 \%$ in ocean water would require nearly doubling the previous size of the ice cap (which seems rather unrealistic), another effect was suggested: a decrease in the ice $\delta^{18} \mathrm{O}$ values. At the same site, isotopic stage 22 also corresponded to the highest percentages of Globigerina pachyderma, a decrease in Globorotalia inflata percentages, and significant changes in G. truncatulinoides coiling ratios.

7. The oxygen isotopic record of Caribbean DSDP Site 502 has allowed Prell (1892) to show statistically two modes of isotopic variation in the Pleistocene with the change in mean isotopic composition occurring about 900,000 yrs. ago. Before 700,000 yrs. ago, the amount of Antarctic Bottom Water entering the western South Atlantic was greatly reduced, and Circum-Polar Deep Water apparently accounted for the bulk of northward flow. A sharp, sustained increase in the volume of bottom water flowing northward occurred after this time.

8. Peterson and Lohmann (1982), proceeding from benthic foraminiferal evidence, suggested a major change in the deep-ocean circulation regime about 890,000 yrs. ago; such a change can also be inferred from carbon isotopic analysis of benthic foraminifers.

Notwithstanding some imprecision about the real timing of this climatic deterioration, it seems to have occurred between 600,000 and 900,000 yrs. ago. For some authors, it should be set at about isotopic stage 19 (the Bruhnes/Matuyama reversal, about 750,000 yrs. ago); for others, it should be around isotopic stage 22; and for yet others, around isotopic stage 24 (the Jaramillo event). It is also recorded in Mediterranean Quaternary sections, where it should correspond to the cold Sicilian Stage (R. Sprovieri, pers. comm., 1982).

At Site 548, numbering of isotopic stages was possible on the planktonic foraminiferal $\delta^{18} \mathrm{O}$ curve down to isotopic stage $16(548-10-4,43 \mathrm{~cm})$. Older stages could not be identified. One may only conclude that, in this region of the northeastern Atlantic, a change between two different glacial modes occurred sometime before isotopic stage 16 (about 600,000 yrs. ago).

\section{Estimated Temperature Changes}

Temperature estimates of Quaternary sequences have already been studied in previous surveys, especially those carried out by the CLIMAP program (Climate Long
Range Investigation Mapping and Prediction). The first investigations on temperature estimates concerned 18,000 yrs. ago, a reference date for maximal glacial conditions (CLIMAP Project Members, 1976). Other recent data on temperature estimates involving areas close to the investigated zone usually concern the last glacial cycle (0-127,000 yrs. ago) (Crowley, 1976; Sancetta et al., 1973; Ruddiman and Glover, 1975; Ruddiman and McIntyre, 1976; McIntyre et al., 1976; Pujol, 1980; Kellogg, 1977). This, we believe, is therefore the first extensive study of an entire Quaternary sequence in the eastern North Atlantic mid-latitudes, in a region where polar-front displacements may have been significant.

At Site 549, however, as the following tabulation shows, discrepancies arise between surface winter temperatures (estimated through transfer functions [Pujol and Duprat, this vol.] for glacial maxima corresponding to isotopic stages $2,6,10$, and 12 ) and isotopic temperatures (calculated by the mean of the simplified equation from Shackleton [1974], using $\delta^{18}$ values measured on benthic foraminifers and a glacial $\delta^{18} \mathrm{O}$ value of $+1.60 \%$ on the PDB scale for NADW):

\begin{tabular}{lccc}
\hline & $\begin{array}{c}\delta^{18} \mathrm{O} \\
\text { equilibrium } \\
\text { values of } \\
\text { benthic } \\
\text { foraminifers }\end{array}$ & $\begin{array}{c}\text { Isotopic } \\
\text { temperatures } \\
\left({ }^{\circ} \mathrm{C}\right)\end{array}$ & $\begin{array}{c}\text { Sea surface } \\
\text { winter temperatures } \\
\left({ }^{\circ} \mathrm{C}\right)\end{array}$ \\
\hline $2^{\mathrm{a}}$ & +5.37 & 1.9 & $\leqq 0$ \\
6 (our results) & +5.27 & 2.2 & $\leqq 0$ \\
10 (our results) & +4.89 & 3.7 & $\leqq 0$ \\
12 (our results) & +4.94 & 2.4 & $\leqq 0$ \\
\hline
\end{tabular}

${ }^{a}$ Core $\mathrm{CH} 73129 \mathrm{C}$ (Duplessy et al., 1980).

Since isotopic temperatures calculated using the $\delta^{18} \mathrm{O}$ value measured at the top of the core $\left(\delta^{18} \mathrm{O}=+3.42\right)$ are compatible with present-day bottom temperatures at Site $549\left(t=+3 \pm 0.4^{\circ} \mathrm{C}\right)$, isotopic temperatures calculated for older stages are also reliable; but one should assume that (1) isotopic deviation for the same foraminiferal species remained constant through time; (2) the effect of ice storage on ocean-water $\delta^{18} \mathrm{O}$ values during older glacial maxima was also constant, and averaged $+1.7 \%$; and (3) bioturbation did not reduce the amplitude of glacial variations. These maximal $\delta^{18} \mathrm{O}$ values occurred at four different times during the last 450,000 yrs.: during isotopic stages 2 (documented in the literature), 6, 10, and 12. At these same times, winter sea-surface temperatures are estimated to have been $0^{\circ} \mathrm{C}$. These four episodes correspond to the times of dominant polar faunas (sinistral $N$. pachyderma contributing to more than $80 \%$ of the total microfaunal assemblages). They were also marked by a low primary productivity, indicated by very low abundances of nannofossils (PujosLamy, pers. comm.). Also during these same periods, benthic foraminiferal assemblages were dominated by Uvigerina peregrina.

It has been shown that, 18,000 yrs. ago (Pujol, 1980), the zone under study was situated north of the polar front and subarctic convergence, where superficial polar waters were in a cyclonic system. The previous consider- 
ations indicate that situations analogous to the one 18,000 yrs. ago prevailed at four times during the past 450,000 yrs. (Fig. 4).

During winter, as we have shown, surface temperatures were lower than deeper ones. This seems to indicate that in that particular zone and during the colder months of the year, vertical profiles of temperatures in the water masses may have been quite similar to those reported for some localities of the Arctic Ocean at the present time (Fig. 5). In the present-day Denmark Straits, for instance, Arctic waters exhibit essentially a two-layered system, with a less dense surface layer separated from the main body of water of quite uniform density by a strong pycnocline, which restricts vertical motion and acts as a lid over the large masses of warmer water below (Coachman and Aagaard, 1974). Planktonic foraminifers which tolerate low temperatures, especially leftcoiling N. pachyderma, could live at greater water depths during such episodes. Coccolithophorids that should not tolerate temperatures below $2^{\circ} \mathrm{C}$ (McIntyre and Bé, 1967) and live in the photic zone became extremely rare during isotopic stages $2,6,10$, and 12 .

These stratified conditions, which prevailed during the colder months of the year, prevented convective overturn and inhibited the establishment of subpolar planktonic foraminiferal assemblages.

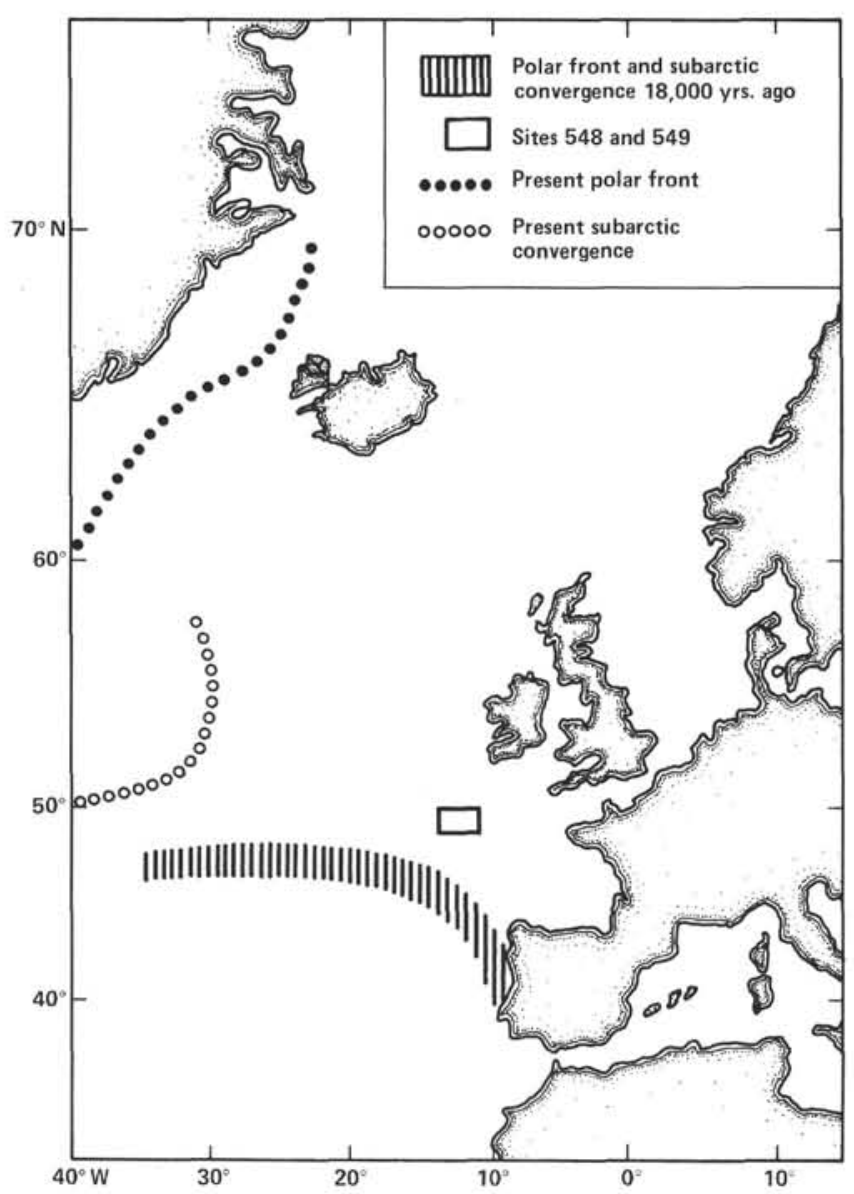

Figure 4. Subarctic convergence and polar front 18,000 yrs. ago and at the present time.

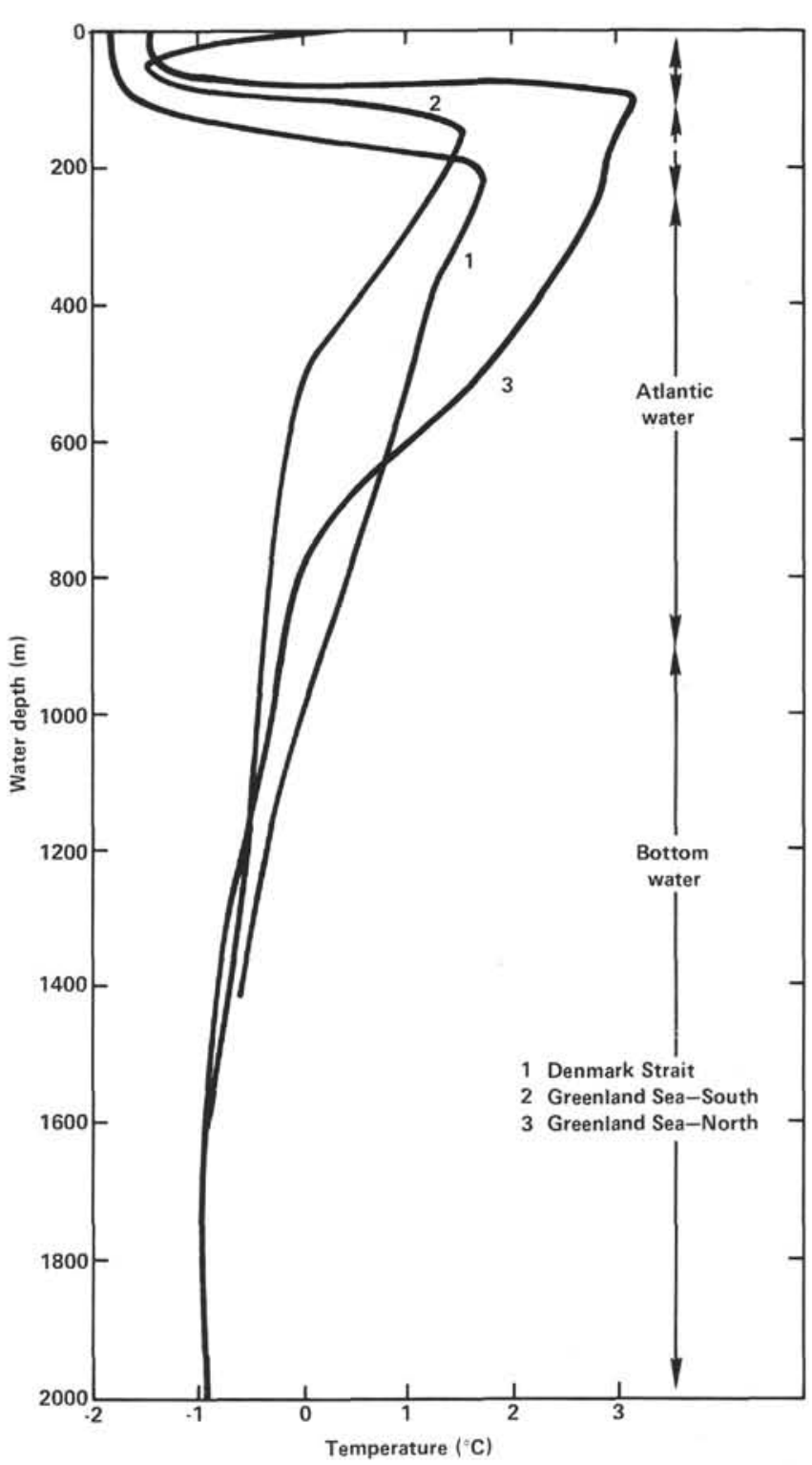

Figure 5. Vertical profiles of temperature in various basins of the Arctic seas.

\section{Deep Water Masses, Oxygen Content, and Circulation}

Fluctuations in the $\delta^{13} \mathrm{C}$ values of benthic foraminifers are recorded at both sites. The last glacial cycle is not documented here but has been studied in great detail by other workers, and isotopic stage 2 correlates with a decrease of about $0.7 \%$ in the $\delta^{13} \mathrm{C}$ of benthic foraminifers (Broecker, 1982). For the older glacial cycles documented here, episodes of ${ }^{13} \mathrm{C}$ depletion may not always correlate with glacial maxima.

At Site 549, episodes of large ${ }^{13} \mathrm{C}$ depletion, mostly recorded by $U$. peregrina, occurred during oxygen-isotopic stages 6 to $7 \mathrm{a}$ and 10 to 12 . At Site $548, \delta^{13} \mathrm{C}$ decreases correlate with episodes of low $\delta^{18} \mathrm{O}$.

At Site 549, the upper Pleistocene $\delta^{13} \mathrm{C}$ values average $+0.16 \%$, significantly lower than the present-day value of $+1.0 \%$ recorded by $P$. wuellerstorfi. But maximal $\delta^{13} \mathrm{C}$ values, between +0.75 and $+1.0 \%$, are reached in 
isotopic stages $7 \mathrm{a}, 7 \mathrm{c}, 8$, and 13 , and minimal $\delta^{13} \mathrm{C}$ values around $-1.3 \%$ are reached in isotopic stage 12 . In oxygen-isotopic stage $6, \delta^{13} \mathrm{C}$ values average $-0.17 \%$, which represents a decrease of $-0.33 \%$ with respect to the average of $+0.16 \%$. In oxygen-isotopic stages 7,11 , and $12, \delta^{13} \mathrm{C}$ values average $-0.50 \%$, which represents a decrease of $-0.66 \%$ relative to the average of $+0.16 \%$.

At Site 548, maximal $\delta^{13} \mathrm{C}$ values are about $+0.75 \%$, and minimal $\delta^{13} \mathrm{C}$ values are between 0 and $-0.25 \%$, the low $\delta^{13} \mathrm{C}$ values corresponding to the low- $\delta^{18} \mathrm{O}$ episodes.

Thus, the two different glacial modes are also characterized by two different sets of $\delta^{13} \mathrm{C}$ values: higher average $\delta^{13} \mathrm{C}$ values with fluctuations of minor amplitude in the lower Pleistocene of Site 548 contrast with lower average $\delta^{13} \mathrm{C}$ values with fluctuations of larger amplitude during the last 450,000 yrs. at Site 549 .

Some hypotheses may now be proposed to explain these differences between the lower and upper Pleistocene and between the two sites.

A first-order explanation is that during the late Pleistocene, North Atlantic Deep Water was less oxygenated and increased its residence time. Peterson and Lohmann (1982) have also shown that microfaunal changes indicate the beginning, between 680,000 and 700,000 yrs. ago, of sustained AABW production at or near presentday volumes in the South Atlantic. This water has a lower oxygen content and a lower $\delta^{13} \mathrm{C}$ of $\mathrm{\Sigma CO}_{2}$ than North Atlantic Deep Water $\left(\delta^{13} \mathrm{C}_{\mathrm{AABW}} \cong+0.6 \% 0\right.$ and $\delta^{13} \mathrm{C}_{\mathrm{NADW}}$ $\cong+1.0 \%$ ). As it progresses northward into the Northern Hemisphere, AABW partially mixes with NADW and may influence NADW's thermal and isotopic characteristics. This scenario could account for lower $\delta^{13} \mathrm{C}$ and higher $\delta^{18} \mathrm{O}$ values in the upper Pleistocene.

Concerning the decreases in $\delta^{13} \mathrm{C}$ during the glacial maxima of the late Pleistocene, there are essentially two basic ways to explain them. A first series of explanations involves a modification of the carbon reservoirs, more precisely a transfer of the carbon from one of the reservoirs to another (Shackleton, 1977; Broecker, 1982). A second series of explanations involves a change in the dynamics of water masses (Streeter and Shackleton, 1979; Boyle and Keigwin, 1982; Curry and Lohmann, 1982). We now present these two series in more detail.

1. Shackleton (1977) noted that $\delta^{13} \mathrm{C}$ values in Core M 123-92 decreased by about $1 \%$ during the glacial period. He attributed this change to a transfer of isotropically depleted, continental, reduced C (from tropical rainforest and northern hardwood forests) into the ocean during glaciations.

More recently, Broecker (1982) argued that this transfer was instead due to a transfer of organic $C$ from the continental shelf into the deep sea.

One would expect, however, that this carbon transfer from extra-oceanic to oceanic reservoir might also be recorded in the $\delta^{13} \mathrm{C}$ values of the $\Sigma \mathrm{CO}_{2}$ of superficial waters; this is generally not the case, and bottom waters alone record this glacial $\delta^{13} \mathrm{C}$ decrease.

2. Following the second series of hypotheses, there is generally rather good agreement that NADW production and/or flow rate were much reduced during some glacial episodes, $\delta^{13} \mathrm{C}$ decrease of deep $\Sigma \mathrm{CO}_{2}$ indicating reduced oxygenation and increased residence time of the deep waters. For some authors, NADW may have been completely eliminated, and for others there may still have been northern sources of NADW.

The formation of NADW requires one or more sources of high-salinity near-surface water from the south; but it also requires particular oceanographic conditions at the source regions, mainly the Labrador and the Norwegian seas. Thus, either a permanent sea-ice cover over the Labrador and the Norwegian seas, preventing thermohaline convection, or a reduction or elimination of highly saline southern sources, is a condition sufficient to modify NADW production. The high-salinity Mediterranean outflow has been hypothesized by Reid (1979) to be an important saline southern source. And this was already taken by Johnson (1982) as an example of reinforcing teleconnection between two water masses. Examination of the fluxes of the different water masses participating in the present-day NADW reveals that the role of the Mediterranean outflow may have been moderate.

Overflow passing through the Denmark Strait and over sills in the Iceland/Scotland Ridge corresponds to a total flux of $6 \times 10^{6} \mathrm{~m}^{3} \mathrm{~s}^{-1}$. This overflow mixes with a $4 \times 10^{6} \mathrm{~m}^{3} \mathrm{~s}^{-1}$ Atlantic flux and forms North Atlantic Deep Water with a total flux of $10 \times 10^{6} \mathrm{~m}^{3} \mathrm{~s}^{-1}$ (Worthington, 1976). Mediterranean outflow at the Gibraltar Straits has a flux of $1.6 \times 10^{6} \mathrm{~m}^{3} \mathrm{~s}^{-1}$. Assuming that all Mediterranean outflow contributes to the Norwegian outflow, it should only represent $16 \%$ of the total NADW. But according to Worthington (1976), part of the Mediterranean outflow (about $60 \%$ ) mixes at $40^{\circ} \mathrm{N}$ with NADW and flows southward, whereas the part contributing to the Norwegian inflow and outflow represents only a few percent, with a flux of about $0.6 \times$ $10^{6} \mathrm{~m}^{3} \mathrm{~s}^{-1}$.

During glacial extremes, the Mediterranean was still active as a deep-water source in the western and eastern basins (Vergnaud Grazzini, in press); but Mediterranean overflow may have been slightly reduced owing to a shallower sill-depth and to a volume loss of $3 \times 10^{5} \mathrm{~km}^{3}$ of water. Thus, a reduction of Mediterranean outflow could not be a sufficient factor in reduction of NADW production. Northern Hemisphere oceanographic conditions in the source region may have been responsible for a reduced NADW flow-rate during some glacial extremes of the last 500,000 yrs. They may be summarized as follows:

A. If sea-ice cover on the Norwegian and Labrador seas (CLIMAP Project Members, 1976) prevented surface-water sinking and deep-water formation by vertical convection, the overlying and underlying less-oxygenated water masses, of Mediterranean origin above and Antarctic origin below, would have become an important part of North Atlantic waters at this particular period.

B. If a two-layered structure of the water masses, inferred from paleotemperature vertical profiles, is a trustworthy figure, such a structure, which may have prevailed throughout part of the year in some regions of the northeastern Atlantic, prevented vertical convection 
and deep-water sinking (as it occurs today at the AABW sources). Thus, average NADW production was reduced. The flux of glacial NADW was diminished relative to that of less-oxygenated water masses.

At shallower Site 548, the correlation that emerges between episodes of low $\delta^{13} \mathrm{C}$ values and low $\delta^{18} \mathrm{O}$ values might be explained also by volume changes in the different water masses. During int/rglacial stages, Mediterranean outflow may have been higher than during glacial stages. North of $45^{\circ} \mathrm{N}$, mixing between Mediterranean waters and the Arctic Intermediate Waters may have been intense, causing large changes in physicochemical parameters and inducing a real but slight $\delta^{13} \mathrm{C}$ decrease in these water masses.

\section{CONCLUSIONS}

Oxygen and carbon isotopic analyses of Quaternary benthic foraminifers at DSDP Sites 548 and 549 (Hole 549A) (mid-latitudes, northeastern Atlantic) give some information on oceanographic conditions in the Quaternary.

At least two different glacial modes may be recognized in the entire Pleistocene, on the basis of stableisotope variations. The lower Pleistocene, probably older than isotopic stage 16 , is characterized by $\delta^{18} \mathrm{O}$ variations of rather low amplitude, averaging $1.65 \%$ between glacial and interglacial extremes, with maximal $\delta^{18} \mathrm{O}$ values averaging $+4.0 \%$. The $\delta^{13} \mathrm{C}$ values, reflecting those of the $\Sigma \mathrm{CO}_{2}$, average $+0.34 \%$, with lower values corresponding to low $\delta^{18} \mathrm{O}$ values. The last 450,000 yrs. appear to correspond to amplified glacial cycles: the glacial-interglacial $\delta^{18} \mathrm{O}$ variation is about $2.2 \%$, and maximal $\delta^{18} \mathrm{O}$ values are about $+5 \%$. Average $\delta^{13} \mathrm{C}$ values are about $+0.15 \%$ and decrease strongly, in correlation with glacial isotopic stages $2,6,7 \mathrm{a}$, and 10 to 12 .

Increased ice storage alone cannot account for the $1 \%$ difference observed between glacial maxima of the lower and upper Pleistocene; a similar difference was also reported for Site 517 on the Rio Grande Rise. Either a decrease in the oxygen isotopic composition of the ice and/or a temperature decrease could account for a change of such magnitude.

Depletion in ${ }^{13} \mathrm{C}$ in the $\Sigma \mathrm{CO}_{2}$ of deep water may reflect - in the upper Pleistocene compared with the lower Pleistocene, as well as in the recent glacial maxima (isotopic stages $2,6,7 \mathrm{a}, 10$ to 12 ) - a modification of oceanographic conditions at deep-water sources.

Before about 600,000 yrs. ago, the amount of Antarctic Bottom Water flowing northward and entering the eastern North Atlantic was greatly reduced. During the last 450,000 yrs., average annual production of NADW diminished during glacial stages, allowing a major inflow of the poorly oxygenated and colder Antarctic Bottom Waters.

\section{ACKNOWLEDGMENTS}

We thank C. Pujol, J. Duprat, A. Pujos-Lamy, A. Longinelli, and E. Vincent for useful discussions; M. J. Urrutiaguer for help in preparing samples for analyses; and B. Corliss for careful review of the manuscript.

Thanks are extended to the Deep Sea Drilling Project members for having made Leg 80 Quaternary samples available for the present study, and to M. Caralp for careful determination of the species analyzed.
The laboratory studies were funded by the Centre National de la Recherche Scientifique, through ERA 0604 and A.T.P. Grant "Geology and Geophysics of the Oceans."

\section{REFERENCES}

Belanger, P. E., 1982. Paleo-oceanography of the Norwegian Sea during the past 130,000 yrs.: coccolithoporid and foraminiferal data. Boreas, 11:29-36.

Belanger, P. E., Curry, N. B., and Matthews, R. K., 1981. Core-top evaluation of benthic foraminiferal isotopic ratios for paleo-oceanographic interpretations. Palaeogeogr. Palaeoclimatol. Palaeoecol., 33:205-220.

Berggren, W. A., 1968. Micropaleontology and the Pliocene-Pleistocene boundary in a deep sea core from the south central North Atlantic. Giorn. Geol. (Bologne), ser. 2, 35(2):291-312.

Berggren, W. A., Phillips, J. D., Bertels, A., and Wall, D., 1967. Late Pliocene-Pleistocene stratigraphy in deep sea cores from the south central North Atlantic. Nature (London), 216:253-254.

Boyle, E. A., and Keigwin, L. D., 1982. Deep circulation of the North Atlantic over the last 200,000 yrs.: geochemical evidences. Science, 218:784-785.

Briskin, M., and Berggren, W. A., 1975. Pleistocene stratigraphy and quantitative paleoceanography of tropical North Atlantic core V 16-205. In Saito, T., and Burckle, L. H. (Eds.), Late Neogene Epoch Boundaries. Micropaleontology Spec. Publ., 1:167-198.

Broecker, W. S., 1982. Glacial to interglacial changes in ocean chemistry. Progr. Oceanogr., 11:151-197.

CLIMAP Project Members, 1976. The surface of the ice-age earth. Science, 191:1131-1137.

Coachman, L. K., and Aagaard, K., 1974. Physical oceanography of arctic and subarctic seas. In Herman, Y. (Ed.), Marine Geology and Oceanography of the Arctic Seas: New York and Berlin, (Springer Verlag), pp. 1-72.

Corliss, B. H., 1982. Linkage of North Atlantic and Southern Ocean deep water circulation during glacial intervals. Nature, 298:458460.

Craig, H., and Gordon, L. I., 1965. Deuterium and oxygen 18 variations in the ocean and the marine atmosphere. In Tongiorgi, E. (Ed.), Stable Isotopes in Oceanographic Studies and Paleotemperatures: Spoleto (CNR), pp. 9-130.

Crowley, T., 1976. Fluctuations of the eastern North Atlantic gyre during the last 150,000 years [Ph. D. thesis]. Brown University.

Curry, W. B., and Lohmann, G. P., 1982. Carbon isotopic changes in benthic foraminifera from the western South Atlantic: reconstruction of glacial abyssal circulation patterns. Quat. Res., 18: 218-235.

Duplessy, J. C., Moyes, J., and Pujol, C., 1980. Deep water formation in the North Atlantic during the last ice age. Nature, 286:479-482.

Emiliani, C., 1955. Pleistocene temperatures. J. Geol. 63:538-578.

1966. Paleotemperature analysis of Caribbean cores $P$ 6304-8 and P 6304-9 and a generalized temperature curve for the last 425,000 years. J. Geol. 74:109-126.

Glass, B., Ericson, D. B., Heezen, B. C., Opdyke, N. O., and Glass, J. A., 1967. Geomagnetic reversals and Pleistocene chronology. $\mathrm{Na}$ ture, 216:437-442.

Graham, D. W., Corliss, B. H., Bender, M. L., and Keigwin, L., Jr., 1981. Carbon and oxygen isotopic disequilibria of recent deep sea benthic foraminifera. Mar. Micropaleontol., 6:483-497.

Johnson, D. A., 1982. Abyssal teleconnections: interactive dynamics of the deep ocean circulation. Palaeogeogr. Palaeoclimatol. Palaeoecol., 38:93-128.

Kellogg, T. B., 1977. Paleoclimatology and paleoceanography of the Norwegian and Greenland seas: the last 450,000 years. Mar. Micropaleontol., 2:235-249.

McIntyre, A., and Bé, A. W. H., 1967. Modern Coccolithophoridae of the Atlantic Ocean: I. Placoliths and cyrtoliths. Deep-Sea Res. 14:561-597.

McIntyre, A., Kipp, N. G., Bé, A. W. H., Crowley, T., Kellogg, T., et al., 1976. Glacial North Atlantic 18,000 years ago: a Climap reconstruction. In Cline, R. M., and Hays, J. D. (Eds.), Investigation of Late Quaternary Palaeoceanography and Palaeoclimatology. Mem. Geol. Soc. Amer., 145:43-76.

Peterson, L. C., and Lohmann, G. P., 1982. Major change in Atlantic deep and bottom waters 700,000 yrs. ago: benthic foraminiferal evidence from the South Atlantic. Quat. Res., 17:26-38. 
Peypouquet, J. P., 1977. Les ostracodes et la connaissance des paléomilieux profonds. Application au Cénozoique de l'Atlantique nord-occidental [Doctoral thesis]. Univ. Bordeaux.

Phillips, J. D., Berggren, W. A., Bertels, S. A., and Wall, D., 1968. Paleomagnetic stratigraphy and micropaleontology of three deep sea cores from the central North Atlantic Ocean. Earth. Planet. Sci. Lett. (Amsterdam), 4:118-130.

Prell, W. L., 1982. Oxygen and carbon isotope stratigraphy for the Quaternary of Hole 502B: evidence for two modes of isotopic variability. In Prell, W. L., Gardner, J. V., et al. Init. Repts. DSDP, 68: Washington (U.S. Govt. Printing Office), 455-464.

Pujol, C., 1980. Les foraminifères planctoniques de l'Atlantique Nord au Quaternaire. Ecologie, stratigraphie, environnement. Mem. Inst. Geol. Bassin Aquitaine, 10.

Reid, J. L., 1979. On the contribution of the Mediterranean Sea outflow to the Norwegian-Greenland Sea. Deep-Sea Res. 26A:11991223.

Ruddiman, W. F., and Glover, L. K., 1975. Subpolar North Atlantic circulation at 93,000 years B. P. Faunal evidence. Quat. Res., 5: 369-389.

Ruddiman, W. F., and McIntyre, A., 1976. Northeast Atlantic paleoclimatic change over the past 600,000 years. In Cline, R. M., and Hays, J. D., (Eds.), Investigation of Late Quaternary Palaeoceanography and Palaeoclimatology. Mem. Geol. Soc. Am., 145: 111-146.

Sancetta, C., Imbrie, J., and Kipp, N. G., 1973. Climatic record of the past 130,000 years in North Atlantic deep sea core V 23-83. Correlation with the terrestrial record. Quat. Res., 3:110-116.

Schnitker, D., 1974. West Atlantic abyssal circulation during the past 120,000 years. Nature, 248:385-387.

, 1976. Structure and cycles of the western North Atlantic Bottom Water, 24,000 yrs. B. P. to present. Trans. Am. Geophys. Union, 57:257-258.

1979. The deep waters of the western North Atlantic during the past 24,000 years, and the re-initiation of the western Boundary Undercurrent. Mar. Micropaleontol., 4:265-280.

, 1980. Quaternary deep sea benthic foraminifera and bottom water masses. Ann. Rev. Earth Planet. Sci., 48:343-370.

, 1982. Climatic variability and deep ocean circulation: evidence from the North Atlantic. Palaeogeogr. Palaeoclimatol. Palaeoecol., 40:213-234.

Shackleton, N. J., 1974. Attainment of isotopic equilibrium between ocean water and the benthonic foraminifer genus Uvigerina: isotopic changes in the ocean during the last glacial. Colloques Intern. Centre Nat. Rech. Sci. (Paris), 219:203-210.
1977. Carbon 13 in Uvigerina: tropical rainforest history and the equatorial Pacific carbonate dissolution cycles. In Anderson, N. R., and Malahoff, A. (Eds.), The Fate of Fossil Fuel $\mathrm{CO}^{2}$ in the Oceans: New York (Plenum), pp. 401-427.

Shackleton, N. J., and Cita, M. B., 1979. Oxygen and carbon isotope stratigraphy of benthic foraminifera at Site 397: detailed history of climatic change during the late Neogene. In von Rad, U., Ryan, W. B. F., et al., Init. Repts. DSDP, 47, Pt. 1: Washington (U.S. Govt. Printing Office), 433-445.

Shackleton, N. J., and Opdyke, N. D., 1973. Oxygen isotope and palaeomagnetic stratigraphy of equatorial Pacific core V 28-238: oxygen isotope temperature and ice volumes on a $10^{5}$ and $10^{6}$ year scale. Quat. Res. 3:39-55.

1976. Oxygen isotope and paleomagnetic stratigraphy of equatorial Pacific core V 28-239, late Pliocene to latest Pleistocene. In Cline, R. M., and Hays, J. D. (Eds.), Investigation of Late Quaternary Palaeoceanography and Palaeoclimatology. Mem. Geol. Soc. Am., 145:449-464.

Streeter, S. S., and Shackleton, N. J., 1979. Paleocirculation of the deep North Atlantic: 150,000 years record of benthic foraminifera and oxygen-18. Science, 203:168-171.

Tchernia, P., 1978. Océanographie régionale: Paris (Ed. Ecole Nat. Sup. Tech. Avancées).

Van Donk, J., 1976. ${ }^{18} \mathrm{O}$ record of the Atlantic Ocean for the entire Pleistocene epoch. In Cline, R. M., and Hays, D. (Eds.), Investigation of Late Quaternary Palaeoceanography and Palaeoclimatology. Mem. Geol. Soc. Am., 145:147-163.

Vergnaud Grazzini, C., Grably, M., Pujol, C., and Duprat, J., 1983. Oxygen isotope stratigraphy and palaeoclimatology of southwest Atlantic Quaternary sediments (Rio Grande Rise) at DSDP Site 517. In Barker, P. F., Carlson, R. L., Johnson, D. A., et al., Init. Repts. DSDP, 72: Washington (U.S. Govt. Printing Office) 871-884.

Vergnaud Grazzini, C., in press. The Mediterranean late Cenozoic stable isotope record: stratigraphic and paleoclimatic implications. Proc. ARI-NATO Conf. Geological Evolution of the Mediterranean Basin (Erice, 1982).

Woodruff, F., Savin, S. M., and Douglas, R. G., 1980. Biological fractionation of oxygen and carbon isotopes by Recent benthic foraminifera. Mar. Micropaleontol., 5:3-11.

Worthington, L. V., 1976. On the North Atlantic Circulation: Baltimore (Johns Hopkins Univ. Press).

Date of Initial Receipt: May 31, 1983

Date of Acceptance: October 26, 1983 